\author{
Bogusław Kowalski
}

\title{
GŁÓWNE KRYTERIA OPTYMALIZACJI OBSŁUGI LOGISTYCZNEJ LUDNOŚCI WOJ. KUJAWSKO-POMORSKIEGO W ŚWIETLE AKTUALNYCH REGULACJI PRAWNYCH
}

Z a rys treści. Systemy społeczno-gospodarcze zmieniane są pod kątem uzyskania bardziej wydajnych działań logistycznych, dotyczących także zasobów ludzkich. Warunkiem ich osiągania jest sprawne funkcjonowanie transportu zbiorowego. Dostarczanie usługi przewozowej dla jak największej liczby osób, o właściwej jakości i po najniższym możliwym koszcie, to proces złożony z wielu elementów. Nowe regulacje wprowadzają rozwiązania, które mają poprawić efektywność jego funkcjonowania. Celem artykułu jest zidentyfikowanie głównych kryteriów optymalizacji tego procesu na przykładzie województwa kujawsko-pomorskiego.

Słow a kluc zow e: usługi publiczne, logistyka, transport.

\section{WSTĘP}

Jednym z wielu kryteriów i narzędzi kształtowania współczesnych systemów społeczno-gospodarczych jest logistyka, ponieważ w konkurencyjnym systemie gospodarki globalnej o sprawności działania decyduje to, aby właściwe zasoby były dostępne we właściwym miejscu i czasie, o właściwej jakości i koszcie. Działania logistyczne, oprócz zasobów rzeczowych i informacyjnych, dotyczą także zasobów ludzkich. Oczekiwania w zakresie odpowiedniej jakości życia współczesnego człowieka wymagają rozbudowanej organizacji funkcjonowania społeczeństw. Składa się na to wiele powiązanych ze sobą procesów, a każdy z nich potrzebuje wsparcia logistycznego. Zarówno praca, nauka, wypoczynek, jak i życie kulturalne, sportowe, religijne i in., aby mogły dojść do skutku i były efektywne, wymagają spełnienia celów logistyki - 6R. 
W rzeczywistości procesy logistyczne stanowią rozwinięte łańcuchy działań, warunkowane różnymi sytuacjami gospodarczymi, ekonomicznymi, infrastrukturalnymi itp. Niemniej z samej istoty logistyki wynika, że każdy proces logistyczny musi zawierać działanie transportowe (Chaberek, 2005, s. 11-19). Również w obsłudze ludności jest to bardzo ważny element, ponieważ dla zapewnienia płynnego przemieszczania się podróżnych kluczowe jest sprawne funkcjonowanie transportu. Gdy dotyczy to mniejszych obszarów, takich jak region lub aglomeracja, oprócz transportu indywidualnego coraz ważniejsze staje się funkcjonowanie transportu zbiorowego. Na obszarach silnie zurbanizowanych ograniczenie występujących tam z coraz większym natężeniem takich negatywnych zjawisk, jak zatłoczenie i zanieczyszczenie środowiska, nie jest możliwe bez rozbudowy i usprawnienia przewozu osób. Jest to złożony i wieloelementowy system. We współczesnym świecie dostarczanie usługi przewozowej o właściwej jakości i po najniższym możliwym koszcie dla jak największej liczby osób, nie jest możliwe w oderwaniu od:

- dostępu do odpowiedniej infrastruktury,

- dysponowania właściwym taborem,

- integracji różnych form transportu przez tworzenie centrów przesiadkowych i jednolitych taryf oraz rozkładu jazdy,

- funkcjonowania sprawnego systemu informacji,

- odpowiedniego wsparcia finansowego ze środków publicznych,

- przyciągnięcia inwestycji ze strony kapitału prywatnego przez odpowiedni system zachęt (Rolbiecki, 2009, s. 199-211; Kowalski, 2010, s. 41-51; Okrasińska, 2011, s. 11-22).

Transport zbiorowy we współczesnych rozwiniętych społeczeństwach jest traktowany jako dobro publiczne (Savas, 1992, s. 47-51; Kleer, 2005, s. 24-35). Odpowiedzialność za jego dostarczanie i właściwe funkcjonowanie ponoszą władze państwowe różnych szczebli. W Polsce, zgodnie z prawnie zapisanymi kompetencjami, są to: minister infrastruktury jako właściwy do spraw transportu, samorządy wojewódzkie, powiatowe, miejskie i gminne. Nowe regulacje prawne zarówno na poziomie Unii Europejskiej w postaci Rozporządzenia nr 1370/2007 Parlamentu Europejskiego i Rady z 23 października 2007 r. dotyczącego usług publicznych $\mathrm{w}$ zakresie kolejowego i drogowego transportu pasażerskiego ${ }^{1}$, jak i Polski w postaci ustawy z 16 grudnia 2010 r. o publicznym transporcie

1 Rozporządzenie nr 1370/2007 PE i Rady UE z dn. 23 października 2007 r. dotyczące usług publicznych w zakresie kolejowego i drogowego transportu pasażerskiego oraz uchylające rozporządzenie Rady (EWG) nr 1191/69 i (EWG) nr 1107/70, Dz. Urz. UE L 315/1 z 03.12.2007. 
zbiorowym ${ }^{2}$ wprowadzają nowe rozwiązania, które mają poprawić efektywność funkcjonowania transportu zbiorowego, a $\mathrm{z}$ uwagi na kompleksowy charakter zmian wpłyną na cały system logistycznej obsługi ludności. Celem artykułu jest zidentyfikowanie głównych kryteriów procesu optymalizacji obsługi logistycznej ludności i opisanie ich na przykładzie województwa kujawsko-pomorskiego.

\section{WYKORZYSTANIE INTEGRACYJNEJ FUNKCJI LOGISTYKI}

W poszukiwaniu sposobów poprawy konkurencyjności w wielu obszarach aktywności społeczno-gospodarczej sięga się po integrację jako proces scalania, zespalania kilku elementów w większą całość (Fiszer, 2006, s. 21). Dzięki temu możliwy jest efekt synergii, wywołany komplementarnością działań objętych integracją. To przynosi wymierne korzyści zarówno w sferze obsługi poszczególnych podmiotów uczestniczących w łańcuchu przepływów, jak i w odniesieniu do efektów ekonomicznych (Chaberek, 2005, s. 32-37). Logistyka zajmuje się integracją procesów przepływu różnych zasobów, w tym zasobów ludzkich. Według M. Chaberka (2002) polega to na realizacji ,wielokierunkowej, wielowarstwowej, wielopodmiotowej koordynacji, współpracy, do jakiej musi dochodzić w procesach przepływu, aby móc osiągnąc cel racjonalizacji kosztowej i wzrost poziomu obsługi klientów. Integracyjne funkcje logistyki są źródłem efektów synergicznych, jakie pojawiają się w łańcuchach logistycznych (...). Zadaniem logistyki jest pokonywanie wszelkich barier pojawiających się w procesach przepływu. Funkcje integracyjne logistyki rozciągają się nie tylko na sferę organizacji procesów, ale też, mając na względzie efektywność ekonomiczną procesów, na ich sferę techniczną i technologiczną".

Również optymalizacja obsługi logistycznej ludności wiąże się z poszerzaniem możliwości integracyjnych i stosowaniem $\mathrm{w}$ praktyce nowatorskich rozwiązań $\mathrm{w}$ tym zakresie. Połączenie $\mathrm{w}$ jeden system różnych form transportu wraz z towarzyszącą temu infrastrukturą przynosi wartość dodaną w postaci wyższej jakości dostarczanej usługi. Podróżny może przemieszczać się w obrębie całej sieci na podstawie jednego biletu, korzystać z krótkich przesiadek i szybko planować podróż dzięki dobrej informacji. Zjawisko synergii pozwala na efektywniejsze wykorzystanie środków publicznych przeznaczanych na

2 Ustawa o publicznym transporcie zbiorowym z dnia 16 grudnia 2010 r., Dziennik Ustaw nr 5/2011, poz. 13 . 
dofinansowywanie usług transportu zbiorowego. Rynek ten jest rynkiem regulowanym, a jego uczestnikami są: konsument, władza państwowa różnych szczebli, podmioty dostarczające usługi oraz podmioty zarządzające infrastrukturą. Dlatego, aby wywołać pożądane działania integracyjne, konieczne są odpowiednie regulacje prawne.

Nowe rozwiązania i narzędzia służące integracji zostały wprowadzone do systemu społeczno-gospodarczego $\mathrm{w}$ ustawie o publicznym transporcie zbiorowym. Jednoznacznie rozdziela się w niej funkcje organizatora publicznego transportu zbiorowego od operatora, którym jest przedsiębiorstwo bezpośrednio dostarczające usługę przewozową. Organizatorem jest odpowiedni organ władzy państwowej, którego zadaniem jest planowanie, organizowanie i zarządzanie publicznym transportem zbiorowym. W ramach wykonywania obowiązku organizowania transportu organy te są zobowiązane do zapewnienia przewoźnikom możliwości dostępu do niezbędnej infrastruktury. W tym organizator zobowiązany jest do zapewnienia funkcjonowania:

1) zintegrowanych węzłów przesiadkowych,

2) zintegrowanego systemu taryfowo-biletowego,

3) jednolitego rozkładu jazdy,

4) systemu pełnej informacji dla pasażera.

Zintegrowany węzeł przesiadkowy oznacza miejsce pozwalające na dogodną przesiadkę z jednego środka transportu do innego. Węzeł taki powinien być wyposażony w odpowiednią infrastrukturę niezbędną dla obsługi podróżnych na oczekiwanym poziomie. Elementami takiej infrastruktury powinny być:

- miejsca postojowe, najlepiej parkingi w systemie ,parkuj i jedź”,

- przystanki komunikacyjne,

- punkty sprzedaży biletów,

- systemy informacyjne o rozkładzie jazdy oraz dostępnych liniach komunikacyjnych.

Natomiast zintegrowany system taryfowo-biletowy to rozwiązanie polegające na stworzeniu możliwości korzystania przez podróżnego $\mathrm{z}$ jednego biletu przy przejeździe różnymi środkami transportu. Dotyczy to tylko obszaru działania jednego organizatora publicznego transportu zbiorowego. Ale w wypadku porozumienia między nimi może to być teren znacznie większy. Ze względów praktycznych rozwiązanie takie powinno obejmować obszar całej aglomeracji. Powinien temu towarzyszyć jeden wspólny rozkład jazdy oraz całościowy, spójny i jednolity system informacji. Za zbudowanie i administrowanie takim systemem odpowiedzialny jest organizator (Ustawa, 2010, art. 4, ust. 26 i 27, art. 43, ust. 1, pkt. 8). Zastosowanie tych rozwiązań pozwala przy stosunkowo niewielkim dodatkowym nakładzie środków uzyskać znaczące podniesienie jakości usługi transportowej, a przez to i całej obsługi logistycznej ludności. Usługa 
transportowa wraz z towarzyszącymi jej działaniami tworzy system wsparcia logistycznego dla regionu, powiatu, aglomeracji miejskiej lub gminy. Jej jakość wpływa na atrakcyjność inwestycyjną i konkurencyjność regionu (Godlewska-Majkowska, 2008, s. 17-21; Ładysz, 2009, s. 7-42).

Tak jak we wszystkich innych województwach, również w województwie kujawsko-pomorskim zgodnie $\mathrm{z}$ ustawą o zbiorowym transporcie publicznym organizatorem transportu o znaczeniu regionalnym jest samorząd wojewódzki. $\mathrm{W}$ jego imieniu zadania te wykonuje marszałek województwa. W wypadku powiatu jest to starosta, a gminy - wójt, burmistrz albo prezydent miasta w zależności od charakteru tej jednostki administracyjnej. Możliwe jest przekazanie kompetencji organizatora do związku międzygminnego lub związku powiatów. Wtedy zadania organizatora wykonuje zarząd związku. Na tych organach władzy państwowej spoczywa odpowiedzialność za organizację transportu publicznego i w ten sposób stymulowanie rozwoju regionalnego. Na wagę problemu wskazuje analiza SWOT (Strategia rozwoju, s.18), według której silną stroną województwa kujawsko-pomorskiego jest „gęsta i równomiernie rozwinięta sieć osadnicza, zapewniająca korzystne warunki obsługi mieszkańców” oraz „centralnie usytuowane ośrodki stołeczne województwa jako bieguny potencjalnego obszaru metropolitalnego". Słabością natomiast jest „niska klasa techniczna i brak urządzeń inżynieryjnych w sieci drogowej” oraz „niedorozwój publicznego transportu pasażerskiego".

Podstawowym celem rozwoju województwa kujawsko-pomorskiego jest poprawa konkurencyjności regionu i podniesienie poziomu życia mieszkańców przy respektowaniu zasad zrównoważonego rozwoju. Cel ten władze województwa chcą osiągnąc m.in. przez wspieranie procesów metropolizacji ośrodków stołecznych Bydgoszczy i Torunia oraz wzmocnienie wysokiego potencjału społeczno-gospodarczego obszaru doliny Wisły, obejmującego oprócz wspomnianych miast stołecznych także Włocławek, Aleksandrów Kujawski, Ciechocinek, Inowrocław, Chełmno, Świecie i Grudziądz. Prowadzić do tego ma zwiększenie spójności układów transportowych wewnątrzregionalnych, m.in. poprzez „stworzenie sieci nowoczesnego, intermodalnego transportu publicznego zapewniającego sprawne, szybkie i bezpieczne połączenia komunikacyjne w obrębie województwa, a także z jego otoczeniem" (Strategia rozwoju, s. 32-33).

Podstawowym sposobem realizacji tego zadania jest połączenie różnych form transportu $\mathrm{w}$ jeden zintegrowany system tworzący łańcuch obsługi logistycznej ludności, przy zastosowaniu zintegrowanych węzłów przesiadkowych, systemów taryfowo-biletowych oraz systemów informacji. Głównymi węzłami przesiadkowymi wyposażonymi w niezbędną infrastrukturę powinny być:

1) port lotniczy w Bydgoszczy, dający możliwość łączenia transportu lotniczego z drogowym i kolejowym, 
2) dworce i stacje kolejowe we wszystkich miejscowościach, w których występuje transport tramwajowy i autobusowy,

3) miejsca krzyżowania się linii tramwajowych z autobusowymi,

4) miejsca stykania się linii żeglugi śródlądowej z liniami kolejowymi, tramwajowymi i autobusowymi.

Podstawą organizacji transportu publicznego w województwie kujawsko-pomorskim powinna być sieć połączeń kolejowych o znaczeniu regionalnym i aglomeracyjnym. Upoważnia do tego istnienie linii kolejowych łączących wszystkie najważniejsze miasta w regionie, w tym zwłaszcza w kluczowej dolinie Wisły. Rozwinięciem sieci kolejowej w miastach powinna być sieć tramwajowa. Poważną szansę stwarza istnienie dogodnej sieci dróg wodnych wzdłuż Wisły i połączenie z rzeką Noteć przez Kanał Bydgoski. Rozbudowa odpowiedniej infrastruktury pozwoliłaby na wykorzystanie tej formy transportu nie tylko do przewożenia towarów i ruchu turystycznego, ale także regularnych przewozów osób w ramach zorganizowanego transportu publicznego. Uzupełnieniem powinien być transport autobusowy.

Węzłom przesiadkowym powinny towarzyszyć wspólne systemy taryfowo-biletowe. Powinny one obejmować co najmniej obszar jednego dużego miasta, ewentualnie w połączeniu z okolicznymi gminami, lub całego powiatu. Dążenie do budowy jednej metropolii łączącej Bydgoszcz i Toruń powinno zaowocować wspólnym biletem na środki komunikacji między nimi i w każdym z tych miast. Możliwe jest też budowanie takiej oferty łączącej miasta blisko siebie położone, jak np. Świecie-Chełmno czy Aleksandrów Kujawski-Ciechocinek, a także obejmujące teren całego województwa. Ważnym elementem jest też stworzenie jednolitego rozkładu jazdy oraz systemu informacji o ofercie przewozowej całej sieci transportu publicznego na terenie województwa oraz w powiązaniu z jego otoczeniem.

\section{PLAN TRANSPORTOWY JAKO NARZĘDZIE INTEGRACJI KOMUNIKACJI PUBLICZNEJ}

Przy funkcjonowaniu czterech szczebli organizatorów transportu publicznego formalnie niezależnych od siebie, poważną trudność sprawiała koordynacja podejmowanych przez nich działań. Dlatego w ustawie o publicznym transporcie zbiorowym najwięksi organizatorzy zostali zobowiązani do opracowania planu zrównoważonego rozwoju publicznego transportu zbiorowego, nazywanego w skrócie planem transportowym. Opisuje on proces rozwoju transportu na danym obszarze, z uwzględnieniem oczekiwań społecznych dotyczących zapewnienia powszechnej dostępności do usług publicznego transportu zbiorowego, 
zmierzający do wykorzystywania różnych środków transportu i promujący przyjazne dla środowiska oraz wyposażone w nowoczesne rozwiązania techniczne środki transportu (Ustawa, 2010, art. 4, ust. 28). Dokumenty te mają charakter aktu planistycznego, ale też prawnie wiążącego. W wypadku ministra właściwego do spraw transportowych jest to ranga rozporządzenia, a organa samorządowe uchwalają je jako akty prawa miejscowego.

Plany transportowe są budowane w układzie hierarchicznym. Ich treść jest ograniczona zapisami planu uchwalonego przez organizatora wyższego szczebla oraz wymaga uzgodnienia $\mathrm{z}$ innymi organizatorami tego samego szczebla. Najpierw powstaje plan krajowy, obejmujący połączenia międzywojewódzkie i międzynarodowe przewozów pasażerskich w transporcie kolejowym. Następnie, uwzględniając zapisy tego planu, marszałkowie województw opracowują plany wojewódzkie. Starostowie uwzględniają te plany, opracowując plany powiatowe, a te z kolei bierze pod uwagę prezydent lub burmistrz i wójt, opracowując plan gminny. Dodatkowo istnieje konieczność uzgodnienia planu z jednostkami sąsiednimi tego samego szczebla. Jeśli sejmik wojewódzki, rada powiatu lub gminy nie uchwali przedłożonego planu transportowego w określonym terminie, plan taki zostanie nadany jednostce administracyjnej przez wojewodę $\mathrm{w}$ trybie nadzorczym. W ten sposób zagwarantowane będzie realizowanie strategii przyjętej dla kraju lub regionu przez organizatorów powiatowych i miejskich.

Istotne kompetencje w zakresie opiniowania planów transportowych oraz zawieranych na ich podstawie umów o świadczenie usług publicznych uzyskuje Prezes Urzędu Transportu Kolejowego (Druk nr 4395, art. 1). Jako organ odpowiedzialny za regulację rynku kolejowego opiniuje przed uchwaleniem wszystkie plany transportowe, w których przewidziane są kolejowe przewozy pasażerskie. Również, gdy takich przewozów dotyczy umowa o świadczenie usług publicznych, zajmuje stanowisko przed jej podpisaniem. Opinia nie ma charakteru wiążącego. Jeśli jest negatywna, nie wstrzymuje procedury i nie uniemożliwia przyjęcia planu lub podpisania umowy w postaci zgodnej z pierwotną wolą organizatora. Opinia służy jedynie przekazaniu przez ekspercki organ fachowego stanowiska, mającego pomóc w doskonaleniu przyjmowanych dokumentów. Ale wiąże się to też z kolejnymi uprawnieniami regulatora, który może odmówić wydania pozwolenia na otwarty dostęp przewoźnika do wybranego odcinka infrastruktury kolejowej, jeśli jego działalność na tej linii wpłynie na warunki ekonomiczne świadczonych tam usług publicznych. Prezes UTK może odmówić otwartego dostępu, jeśli spowoduje to:

1) wzrost poziomu rekompensaty wypłacanej za świadczone usługi publiczne o ponad $10 \%$,

2) zakłóci regularność przewozów pasażerskich z uwzględnieniem natężenia ruchu na linii kolejowej oraz potrzeb podróżnych. 
Regulator uzyskał też dodatkowe uprawnienia w zakresie nadzoru nad procesem negocjacji i zawierania umów między przewoźnikami kolejowymi a zarządcami infrastruktury. W wypadku braku porozumienia między nimi Prezes UTK, dla zachowania ciągłości ruchu, może wydawać tymczasowe decyzje o udostępnieniu infrastruktury przewoźnikom. Także już zawarte umowy na dostęp mogą być rozwiązane przed terminem jedynie za zgodą regulatora. Prezes UTK kontroluje także jakość wykonywanych kolejowych przewozów pasażerskich. Został wyposażony w narzędzia pozwalające na zapobieganie rażącym przypadkom naruszania wymogów w tym zakresie, zapisanych w planach transportowych, a wykonywanych zarówno przez przewoźników komercyjnych, jak i w ramach służby publicznej. Wzmocnienie roli regulatora rynku kolejowego jest konsekwencją zapisów przyjętych w ustawie o publicznym transporcie zbiorowym oraz negatywnych doświadczeń związanych z dezorganizacją rynku w grudniu 2010 r. (Druk nr 4395, uzasadnienie).

Do uchwalenia planów transportowych zobowiązani są:

- minister do spraw transportu,

- wszystkie samorządy wojewódzkie,

- powiaty o liczbie mieszkańców co najmniej 80 tys. lub związek powiatów liczący łącznie co najmniej 120 tys. mieszkańców,

- gminy liczące co najmniej 50 tys. mieszkańców lub związek międzygminny liczący co najmniej 80 tys. mieszkańców.

Ustawa dopuszcza uchwalanie planów transportowych przez jednostki administracyjne, liczące mniej mieszkańców, ale nie są one obligatoryjne (Ustawa, 2010, art. 9).

Z powyższych ustaleń ustawowych wynika, że do województwa kujawsko-pomorskiego odnoszą się następujące plany transportowe:

- krajowy, opisujący skomunikowanie regionu z otoczeniem krajowym i międzynarodowym dzięki odpowiednim pasażerskim połączeniom kolejowym,

- wojewódzki w zakresie sieci komunikacyjnej przewozów pasażerskich o znaczeniu wojewódzkim,

- powiatowe: w powiatach grodzkich - Bydgoszcz, Toruń, Włocławek, Grudziądz - oraz ziemskich - bydgoskim, inowrocławskim, nakielskim, świeckim, toruńskim i włocławskim - obejmujące sieć połączeń powiatowych,

- gminny w Inowrocławiu, obejmujący połączenia w tym mieście ( $L u d$ ność, ruch naturalny i migracje, 2009, s. 38-42).

Możliwe jest też uchwalanie planów transportowych przez związki międzygminne lub związki powiatów. Zawarte 20 kwietnia 2005 r. porozumienie partnerskie w sprawie Bydgosko-Toruńskiego Obszaru Metropolitalnego między 
marszałkiem województwa a prezydentami Bydgoszczy i Torunia oraz starostami ziemskimi z powiatów ziemskich bydgoskiego i toruńskiego nie ma jednak takiego charakteru. Niemniej może to być forum uzgadniania wspólnych rozwiązań integrujących transport zbiorowy na tym obszarze, które następnie znajdą swoje odbicie w planach transportowych poszczególnych organizatorów.

Plan transportowy powinien zawierać przede wszystkim:

- określenie sieci komunikacyjnej, na której planowane jest wykonywanie przewozów o charakterze użyteczności publicznej,

- ocenę i prognozy potrzeb przewozowych,

- przewidywane finansowanie usług przewozowych,

- preferencje dotyczące wyboru rodzaju środków transportu,

- zasady organizacji rynku przewozów,

- pożądany standard usług przewozowych w przewozach o charakterze użyteczności publicznej,

- przewidywany sposób organizowania systemu informacji dla pasażera (Ustawa, art. 12, ust. 1).

Plany transportowe opisują organizację i finansowanie transportu zbiorowego na terenie całego województwa w sposób ogólny, z uwzględnieniem wszystkich połączeń o charakterze regionalnym, oraz w sposób bardziej szczegółowy na terenach silnie zurbanizowanych, z uwzględnieniem połączeń o charakterze powiatowym i miejskim. W ten sposób w postaci planów transportowych organizatorzy, a zwłaszcza władze regionalne, otrzymały dodatkowe narzędzie pozwalające na zastosowanie nowych rozwiązań integrujących transport publiczny.

\section{ZASADA ROZSĄDNEGO ZYSKU DODATKOWYM ŹRÓDŁEM FINANSOWANIA INWESTYCJI}

Właściwe funkcjonowanie zbiorowej komunikacji wymaga angażowania adekwatnych środków finansowych. Pozyskanie tych środków należy do obowiązków organizatora. Mogą one pochodzić z:

- budżetu jednostki samorządu terytorialnego będącej organizatorem,

- budżetu państwa,

- funduszy Unii Europejskiej, ale wyłącznie na inwestycje w infrastrukturę i tabor,

- $\quad$ wpływów ze sprzedaży biletów i opłat dodatkowych.

Nowe regulacje prawne tworzą dodatkowe narzędzia, które mają umożliwić organizatorowi bardziej efektywne wykorzystanie środków publicznych przeznaczanych na finansowanie transportu. Są to:

1) wprowadzenie rozwiązań integracyjnych i korzystanie z efektu synergii, 
2) dopuszczenie konkurencji przy zawieraniu umów na świadczenie usług transportowych w ramach służby publicznej,

3) możliwość pobierania opłat od operatorów za korzystanie z przystanków i dworców w komunikacji autobusowej,

4) udostępnianie operatorom środków transportu zakupionych $\mathrm{z}$ budżetu lub funduszy unijnych dla świadczenia usług transportowych w ramach służby publicznej.

Zastosowanie tych narzędzi nie spowoduje jednak powstania na tyle znaczących oszczędności, aby w ramach dotychczasowych środków, będących w dyspozycji organizatorów, możliwe było znaczne zwiększenie nakładów na modernizację infrastruktury i zakup taboru (Raport NIK, 2010, s. 5-9, 24-50). W Bydgoszczy, największym mieście w województwie kujawsko-pomorskim, w latach 2004-2008 następował systematyczny wzrost wydatków na transport, ale mimo to w 2008 r. kwota ustalona w planie wydatków stanowiła jedynie $82,7 \%$ zgłaszanych potrzeb. Wysiłki te przyniosły efekt w postaci zwiększenia liczby pasażerów korzystających z komunikacji miejskiej w 2008 r. w stosunku do 2003 r. o $15 \%$. W tym czasie stan taboru tramwajowego nie uległ jednak istotnej poprawie. Mimo przyjętych planów, w tym okresie długość i liczba linii tramwajowych nie uległa zmianie. Zaplanowano również utworzenie 6 tras drogowych o przyspieszonym ruchu o łącznej długości ok. 45,2 km. W latach 2003-2008 zrealizowano z tego tylko 1,6 km, czyli 5,6\% planu. To pokazuje skalę potrzeb w zakresie rozbudowy infrastruktury i zakupu nowych środków transportu. Podobna sytuacja występuje w innych miastach w Polsce (Raport NIK, tab. 2, s. 24-25, 27, 37, 47).

Szansą na częściową poprawę tego stanu rzeczy jest zaangażowanie kapitałów prywatnych. Rozwojowi partnerstwa publiczno-prywatnego w transporcie publicznym powinno sprzyjać stosowanie zasady rozsądnego zysku. Jest o nim mowa w załączniku do Rozporządzenia (WE) nr 1370/2007. W załączniku tym zostały opisane zasady stosowane do przyznawania rekompensaty należnej operatorowi na podstawie zawartej z organizatorem umowy o świadczenie usług publicznych. Rekompensata ta powinna być obliczana według następującego wzoru:

$$
K-W-P t+Z=W f n
$$

gdzie znaczenie poszczególnych symboli jest następujące:

$K$ - koszty poniesione w związku ze zobowiązaniem z tytułu świadczenia usługi publicznej,

$W$ - wpływy finansowe wygenerowane na sieci obsługiwanej w ramach danego zobowiązania z tytułu świadczenia usług publicznych, 
$P t$-przychody taryfowe i inne wygenerowane w ramach realizacji danego zobowiązania,

$Z$ - rozsądny zysk - stopa zwrotu z kapitału, która w danym państwie członkowskim uznawana jest za normalną dla tego sektora działalności i w której uwzględniono ryzyko lub brak ryzyka ingerencji organu publicznego, ponoszonego przez podmiot świadczący usługi publiczne (Rozporządzenie, 2007, art. 6, ust. 1, załącznik pkt. 2; Wiśniewski, 2009, s. 6).

Stosowanie zasady rozsądnego zysku w Polsce zostało potwierdzone w Ustawie o publicznym transporcie zbiorowym. Prawo do korzystania z rozsądnego zysku mają jedynie ci operatorzy, którzy zostali wyłonieni w drodze postępowania przetargowego. Ustawodawca nałożył też obowiązek na ministra właściwego do spraw finansów publicznych, aby w porozumieniu z ministrem właściwym do spraw transportu ustalił $\mathrm{w}$ drodze rozporządzenia sposób określania wysokości rozsądnego zysku. Ma przy tym brać pod uwagę:

- rodzaj transportu,

- kapitał, od którego należy liczyć wysokość rozsądnego zysku,

- konieczność zapobiegania nadmiernemu poziomowi rekompensaty (Ustawa, 2010, art. 52, ust. 2-4).

Jeśli wysokość rozsądnego zysku zostanie ustalona na atrakcyjnym dla dysponentów kapitałów poziomie, zwłaszcza jeśli będzie konkurencyjna w stosun$\mathrm{ku}$ do stopy zysku z obligacji rządowych oraz przy zastosowaniu wieloletnich umów, wówczas możliwe jest przyciągnięcie do inwestycji w transport publiczny znacznych środków uzupełniających nakłady z funduszy publicznych. Umowa na świadczenie usług w transporcie drogowym może być zawarta na 10 lat, a w transporcie kolejowym nawet na 15 lat. Jest to wystarczająco długi okres, aby zamortyzować środki trwałe, w tym zakupiony tabor, oraz zrealizować stabilny, bo zagwarantowany w umowie o świadczenie usług, zysk.

Władze województwa kujawsko-pomorskiego mają pewne doświadczenie we wprowadzaniu modelu partnerstwa publiczno-prywatnego do obsługi publicznego transportu zbiorowego. W 2007 r. przetarg na wykonywanie przewozów pasażerskich obejmujących kolejowe linie spalinowe w tym województwie, ogłoszony przez samorząd wojewódzki, wygrała Arriva PCC Sp. z o.o., należąca do angielskiego koncernu transportowego Arriva. W późniejszym okresie grupa Arriva stała się własnością Deutsche Bahn, a te z kolei należą do państwa niemieckiego. Trudno więc mówić tu o klasycznym przykładzie partnerstwa publiczno-prywatnego, ale wykonujące przewozy w województwie kujawsko-pomorskim przedsiębiorstwo Arriva RP Sp. z o.o., będące prostym kontynuatorem Arriva PCC Sp. z o.o., jest nowym operatorem na polskim rynku przewozów z dostępem do innych funduszy niż polskie i unijne środki publiczne. 
W wyniku wygranego przetargu podpisano 3-letnią umowę ramową na świadczenie usług z marszałkiem województwa kujawsko-pomorskiego. Linie, na których operuje Arriva, stanowią prawie $40 \%$ połączeń pasażerskich w regionie. Przewozy są wykonywane nowymi autobusami szynowymi PESA, udostępnionymi przez organizatora, oraz zmodernizowanymi duńskimi składami zespolonymi typu MR, sprowadzonymi przez operatora. Poważną barierą w dalszej poprawie jakości jest zły stan infrastruktury. W 2009 r. z usług tego przewoźnika skorzystały $3 \mathrm{mln}$ pasażerów. Władze wojewódzkie, dzięki tańszej ofercie Arrivy zgłoszonej w przetargu, dopłacają do wykonywanych połączeń ok. $10 \mathrm{mln}$ zł rocznie mniej. Środki te mogą być przeznaczone na inne cele publiczne. Wejście nowego przewoźnika nie obyło się bez problemów organizacyjnych i technicznych. Mimo stosunkowo dobrej jakości usług świadczonych przez Arrivę oferta ta nie jest zintegrowana z innymi przewoźnikami ${ }^{3}$. Dysponując nowymi narzędziami i własnym doświadczeniem praktycznym, władze regionalne w porozumieniu z organizatorami na niższych szczeblach mogą wprowadzać nowe rozwiązania na szerszą skalę, także w zakresie finansowania, i przez to skuteczniej doskonalić model funkcjonowania publicznego transportu zbiorowego, będący podstawą logistycznej obsługi ludności w województwie kujawsko-pomorskim.

\section{ZAKOŃCZENIE}

Nowe regulacje prawne, wyraźnie rozdzielając rolę organizatora i operatora, porządkują rynek usług transportu publicznego. Jednocześnie doprecyzowane i ustabilizowane zostały relacje między nimi, które będą oparte o plan transportowy i umowę o świadczenie usług publicznych. Organizator został wyposażony w nowe narzędzia organizacji i finansowania publicznego transportu zbiorowego wraz z niezbędną infrastrukturą, które są podstawą systemu logistycznej obsługi ludności. Przykład województwa kujawsko-pomorskiego pokazuje, że podstawowy szkielet tego systemu jest planowany, a następnie realizowany na poziomie regionalnym i aglomeracyjnym. Centralnym narzędziem służącym temu mogą się stać plany transportowe, które powinny pomóc w koordynacji współpracy między organizatorami różnych szczebli. Wynikiem tej koordynacji powinna być integracja odmiennych form transportu w jeden system, przy zastosowaniu takich rozwiązań, jak zintegrowane węzły przesiadkowe, wspólne systemy taryfowo-biletowe, jednolity rozkład jazdy i towarzyszące temu całościowe systemy informacyjne.

3 http://www.arriva.pl/pl/o-nas/historia/, http://www.arriva.pl/pl/o-nas/arriva-rp-sp-z-oo/, http://www.arriva.pl/pl/o-nas/arriva-ple/ 
Poważnym wyzwaniem jest finansowanie systemu. Doświadczenia województwa kujawsko-pomorskiego wskazują, że trwałe podniesienie jakości obsługi logistycznej ludności wymaga znacznych nakładów finansowych na modernizację i rozbudowę infrastruktury transportowej. Pewne kwoty można wygospodarować z puli przeznaczanej na bieżące utrzymanie systemu. Jest to możliwe poprzez wprowadzenie konkurencji między przewoźnikami w rywalizacji o możliwość podpisania wieloletniej umowy o świadczenie usług publicznych oraz wynika z efektu synergii przy zastosowaniu rozwiązań integracyjnych. Dodatkowym narzędziem jest zasada rozsądnego zysku, która precyzując reguły współpracy z kapitałem innym niż publiczny, pozwala na stosowanie różnych rozwiązań z zakresu partnerstwa publiczno-prywatnego także do finansowania inwestycji taborowych i infrastrukturalnych.

\section{LITERATURA}

Chaberek M. (2005), Makro- i mikroekonomiczne aspekty wsparcia logistycznego, Wydawnictwo Uniwersytetu Gdańskiego, Gdańsk.

Chaberek M. (2002), Wsparcie logistyczne działalności gospodarczej jako podstawa kształtowania wspótczesnych strategii konkurencji, „Studia Gdańskie. Wizje i rzeczywistość", Gdańsk.

Druk $n r 4395$ Sejmu $R P$ zawierający rządowy projekt ustawy o zmianie ustawy o transporcie kolejowym z 29 czerwca $2011 \mathrm{r}$.

Fiszer J. M., (2006), Unia Europejska a Polska - dziś i jutro, Wydawnictwo Adam Marszałek, Torun.

Godlewska-Majkowska H., red. (2008), Atrakcyjność inwestycyjna polskich regionów. $W$ poszukiwaniu nowych miar, Szkoła Główna Handlowa w Warszawie, Warszawa.

Informacja o wynikach kontroli działań podejmowanych na rzecz usprawnienia systemu transportowego w największych miastach w Polsce, nr ewid. 4/2010/P/09/178/LWA, Najwyższa Izba Kontroli, Warszawa maj 2010.

Kleer J. (2005), Identyfikacja rodzajów dóbr wytwarzanych przez sektor publiczny, [w:] Sektor publiczny w Polsce i na świecie - między upadkiem a rozkwitem, red. J. Kleer, CeDeWu, Warszawa.

Kowalski B. (2010), Obszary obstugi informatycznej w kolejowych przewozach regionalnych na przykładzie Kolei Mazowieckich, [w:] Informatyczne narzędzia procesów logistycznych, red. M. Chaberek, A. Jezierski, CeDeWu, Warszawa.

Ludność, ruch naturalny i migracje w województwie kujawsko-pomorskim w 2008 r., Urząd Statystyczny w Bydgoszczy, sierpień 2009.

Ładysz I. (2009), Konkurencyjność obszarów metropolitalnych w Polsce na przykładzie wrocławskiego obszaru metropolitalnego, CeDeWu, Warszawa.

Okrasińska I. (2011), Infrastruktura a jakość ustug $w$ transporcie kolejowym w Polsce, „Zeszyty Naukowe Doktorantów Wydziału Ekonomicznego Uniwersytetu Gdańskiego" nr 1, Wydawnictwo Uniwersytetu Gdańskiego, Gdańsk. 
Rolbiecki R. (2009), Infrastruktura transportu jako czynnik kształtujący warunki rozwoju przedsiębiorstw w otoczeniu spoleczno-gospodarczym, Wydawnictwo Uniwersytetu Gdańskiego, Gdańsk.

Rozporzadzenie nr 1370/2007 PE i Rady UE z dn. 23 października 2007 r. dotyczace ustug publicznych $w$ zakresie kolejowego i drogowego transportu pasazerskiego oraz uchylajace rozporzadzenie Rady (EWG) nr 1191/69 i (EWG) nr 1107/70, Dz. Urz. UE L 315/1 z 03.12.2007

Savas E. S. (1992), Prywatyzacja. Klucz do lepszego rządzenia, Państwowe Wydawnictwo Ekonomiczne, Warszawa.

Strategia rozwoju województwa kujawsko-pomorskiego na lata 2007-2020, załącznik do Uchwały Nr XLI/586/05 Sejmiku Województwa Kujawsko-Pomorskiego z dnia 12 grudnia 2005 r., Toruń, listopad 2005

Ustawa o publicznym transporcie zbiorowym z dnia 16 grudnia 2010 r., Dziennik Ustaw nr 5/2011, poz. 13.

Wiśniewski A. (2009), Finansowanie regionalnego transportu pasażerskiego w Polsce w latach 2005-2008, Praca dyplomowa w ramach podyplomowych studiów menedżerskich „Europejski Model Zarządzania” zrealizowanych dla Związku Pracodawców Kolejowych przez Gdańską Fundację Kształcenia Menedżerów i Wyższą Szkołę Przedsiębiorczości i Zarządzania im. Leona Koźmińskiego w Warszawie, czerwiec 2009.

http://www.arriva.pl/pl/o-nas/historia/.

http://www.arriva.pl/pl/o-nas/arriva-rp-sp-z-oo/.

http://www.arriva.pl/pl/o-nas/arriva-plc/.

\section{THE MAIN CRITERIA OF THE OPTIMIZING OF LOGISTIC SERVICE OF THE POPULATION OF THE KUJAWSKO-POMORSKIE IN LIGHT OF CURRENT LEGAL REGULATIONS}

A bstract: Socio-economic systems are modified to achieve more efficient logistics, concerning the human resources. The condition for achieving them is the smooth functioning of collective transport. Providing a transport service for the greatest number of people at the right quality at the lowest possible cost is a complex process with many elements. The new legal regulations in EU and Poland bring solutions in terms of organization and financing to improve the efficiency of its operation. The article aims to identify the main criteria for the optimization of this process on the example of the Kujawsko-Pomorskie.

K e y w o rd s : public services, logistics, transport. 